\title{
EFFECT OF NITROGENOUS SOIL AMMENDMENTS ON SOIL PHYSICO-CHEMICAL PROPERTIES AND PERFORMANCE OF CASTORBEAN PLANT (Ricinus communis) IN RIVERS STATE, NIGERIA
}

\author{
OBIANUJU ADAOBI ORJI \\ Department of Crop/Soil Science, Rivers State University \\ P. M. B. 5080, Port Harcourt, Nigeria.
}

DOI: 10.46609/IJAER.2020.v06i03.003 URL: https://doi.org/10.46609/IJAER.2020.v06i03.003

\begin{abstract}
The castor bean seed when cooked and fermented, is a staple food condiment in Nigeria, but its production is low in the humid rainforest zone of Southern Nigeria. A field experiment was conducted in the Rivers State University Teaching and Research Farm in Port Harcourt Nigeria, to evaluate the effect of various nitrogenous soil amendments on the growth and yield of castor bean plant (Ricinus communis). The treatments included $120 \mathrm{kgNha}^{-1}$ equivalent of urea, NPK 20-10-10, poultry droppings, piggery dung and no amendment (control). These were replicated thrice and laid out in randomized complete block design. A Chinese improved variety of castor bean plant (Zibocastor No 5) was planted at a spacing of $1 \mathrm{~m}$ x $1 \mathrm{~m}$ within and between row, at a population of 5,000 seeds per hectare. Results showed that the various nitrogenous soil amendments significantly affected all growth and yield parameters measured, but germination was negatively affected. Piggery dung gave the best values of $52.6 \mathrm{~cm}, 24.0,85.0 \mathrm{~cm}^{2}, 191.5$, and 350 gplant $^{-1}$ for plant height, number of leaves, leaf area, number of capsules and capsule weight respectively, when compared to the control with $24.5,8.0,40.0 \mathrm{~cm}^{2}, 28.4,153$ gplant $^{-1}$. Results of the physico-chemical properties of the soil showed significant increase in total nitrogen and available phosphorus, and a decrease in exchangeable calcium and magnesium with no significant changes in $\mathrm{pH}$; following soil amendment and cropping. Amending the soil with piggery dung increased yield by $397.0 \%$ over the control.
\end{abstract}

Keywords: Castor bean, Soil, Nitrogenous amendments

\section{INTRODUCTION}

The castor bean plant (Ricinus communisi) is a specie of flowering plants in the spurge family: Euphorbiaceae (Weiss, 2000). Castor is indigenous to the southeastern Mediterranean basin, east African and India, but it is widespread throughout the tropical region (Orji and Eke 2018). 
International Journal of Agriculture and Environmental Research

ISSN: 2455-6939

Volume: 06, Issue: 03 "May-June 2020"

This crop is cultivated for its seeds, which contain up to $45 \%$ of fast-drying natural oil rich in ricinoleic acid used mainly in medicines and industry (Hussein et al., 2015). It is reported to be nutritious and high in protein, lipid and calcium contents (Obizoba and Atu, 1993). In Nigeria, castor bean oil is widely used to induce labour in pregnant women. When cooked and fermented, it is also used as a staple food condiment (ogiri) for soups and traditional dishes (Obizoba and Atu, 1993).This high yielding and short duration crop with its wide range of uses and global demand has become a cash crop in modern agriculture. Studies on its adaptability in different soils have been done in a number of countries (Orji and Eke 2018 and Mabuza and Mabuza 2019). Previous studies have also reported significant increase in growth and yield with addition of nitrogenous fertilizers. (Reddy and Matcha 2010; Mabuza and Mabuza 2019). In the humid rainforest region of Rivers State Nigeria, castor bean production is still low with little information on its production. The aim of this study was to evaluate the effect of various nitrogenous fertilizers on the performance of the castor bean plant and soil properties.

\section{MATERIALS AND METHODS}

The experiment was conducted at the Teaching and Research Farm of the Rivers State University of Science and Technology, Port Harcourt, with a mean annual rainfall ranging between 3000 and $4000 \mathrm{~mm}$ (Okonkwo, 2010) and average annual temperature of about $23^{\circ} \mathrm{C}$.

The castor bean seed used for the experiment was a Chinese improved variety of castor bean called the Zibo Castor No5; a middle maturing hybrid variety bred by Zibo Academy of Agricultural Sciences (Chinese Hybrid Castor). The nitrogenous soil amendments used were Urea and NPK 20:10:10 which were procured from the Rivers State Agricultural Development Programme. Poultry droppings and piggery dung were obtained from the Teaching and Research Farm of the Rivers State University Nigeria.

Based on the percentage of nitrogen in the nitrogenous fertilizers, the treatments consisted of $120 \mathrm{kgNha}^{-1}$ equivalent of Urea, NPK 20:10:10, piggery dung, poultry droppings and then a control with no nitrogenous amendment. The treatments were replicated thrice and laid out in a randomized complete block design (RCBD). The plots were manually cleared and ridged; to provide for a good soil tilth. The castor bean seeds were planted one seed per hole at a depth of $3 \mathrm{~cm}$ into the soil and at a spacing of $1 \mathrm{~m} \times 1 \mathrm{~m}$ within and between rows. This gave a total plant population of 5,000 seeds per hectare. Between ridges was $2 \mathrm{~m}$ spacing. Missing stands were supplied at 2 weeks after planting (WAP). Plots were kept weed free by hoeing and handpicking at 2,4 and 6WAP. The various sources of nitrogenous fertilizers were applied wholly at 2WAP; using the band placement method at a $20 \mathrm{~cm}$ radius from the plant.

Surface soil samples $(0-15 \mathrm{~cm}$ depth) were collected randomly from the experimental site before treatment application and from the various plots after harvest. The soil samples were air-dried 
and sieved with a $2 \mathrm{~mm}$ mesh size sieve and subjected to routine analysis as described by Page $e t$ al. (1982). Organic matter was determined by the wet dichromate oxidation method (Nelson and Sommers, 1982), total nitrogen by the micro kjeldahl method, (Bremner and Mulvaney,1982), available Phosphorus by Bray-1 extraction followed by molybdenum blue-colorimetry, exchangeable cations (calcium, magnesium and potassium) were extracted with ammonium acetate (Thomas, 1982).

The following growth and yield parameters were estimated from $50 \%$ of the stands planted on each plot: percentage germination of seeds, plant height and number of leaves, leaf area and yield (number and weight of capsules). Data collected were subjected to analysis of variance for an RCBD and means were separated using the Least Significant Difference.

\section{RESULTS AND DISCUSSION}

\subsection{Effect of Nitrogenous Amendments on Soil Properties}

The physico-chemical properties of the test soil before treatment application is as shown on Table 1. The sandy loam soil is acidic and low in organic matter content, and exchangeable cations. These conditions are typical of the Ultisols of Southern Nigeria; given their acid parent material (Lal, 1986).

Table1: Properties of The Soil of The Experimental Site Before Treatment Application

\begin{tabular}{ll}
\hline Property & Value \\
\hline $\mathrm{pH}\left(\mathrm{H}_{2} \mathrm{O}\right)$ & 5.20 \\
Organic Carbon (\%) & 0.97 \\
Organic matter (\%) & 1.67 \\
Total Nitrogen (\%) & 0.21 \\
Exchangeable acidity $\left(\mathrm{cmolkg}^{-1}\right)$ & 1.52 \\
Exchangeable cations $\left(\mathrm{cmolkg}^{-1}\right)$ & \\
$\quad \checkmark \quad \mathrm{Ca}^{2+}$ & 13.20 \\
$\quad \checkmark \quad \mathrm{Mg}^{2+}$ & 1.30 \\
& 27.25 \\
Available P $\left(\mathrm{mgkg}^{-1}\right)$ & 73.3 \\
$\%$ sand & 4.0 \\
\% Silt &
\end{tabular}


International Journal of Agriculture and Environmental Research

ISSN: 2455-6939

Volume: 06, Issue: 03 "May-June 2020"

\%Clay

Texture

\section{7}

Sandy loam

The soil properties as affected by the nitrogenous amendments is as shown on Table 2. Particle size distribution and texture were not affected by the amendments. This is not unexpected as the percentage of sand, silt and clay fractions of soil, are not likely to be affected by addition of fertilizers within a short period of time.

Soil $\mathrm{pH}$ was generally not affected by the various treatments. Exchangeable acidity was observed to be significantly lower in soils amended with inorganic sources of nitrogen; which includes urea and NPK 20-10-10 with values ranging between 1.22 to $1.42 \mathrm{cmolkg}^{-1}$ when compared with soils treated with the organic sources including poultry manure and piggery dung which has the same values with the untreated soil of $1.54 \mathrm{cmolkg}^{-1}$. Calcium and magnesium contents of the soils were also not affected by the various nitrogenous amendments; except for the soil treated with the piggery dung where calcium content was significantly reduced to $8.8 \mathrm{cmolkg}^{-1}$ when compared with the control of $12.2 \mathrm{cmolkg}^{-1}$.

Organic matter contents were significantly lower in urea treated soils when compared with all the other treatments. The generally low organic matter contents across all the treatments may have been as a result of the very low carbon:nitrogen $(\mathrm{C} / \mathrm{N})$ ratio ranging between 1.3 to 5.6; even with the amendments.

The total percentage nitrogen contents were significantly increased in all the amended soils; with urea amended soils having a percentage nitrogen content of $0.84 \%$ when compared with the unamended soil of $0.28 \%$. Urea being a single nitrogen fertilizer with a high percentage of nitrogen content may have contributed to this trend. Available phosphorus was significantly enhanced by the nitrogenous amendments; particularly with the NPK 20-10-10 fertilizer and the piggery dung. The available $\mathrm{P}$ values were 43.85 and $35.08 \mathrm{mgkg}^{-1}$ for NKP $20-10-10$ and piggery dung respectively, when compared with the control of $29.81 \mathrm{mgkg}^{-1}$. 
International Journal of Agriculture and Environmental Research

ISSN: 2455-6939

Volume: 06, Issue: 03 "May-June 2020"

Table 2: Soil Properties as Affected by Nitrogenous soil amendments after harvest

\begin{tabular}{|c|c|c|c|c|c|}
\hline \multirow[t]{3}{*}{ Properties } & \multicolumn{5}{|c|}{$\longleftarrow$ Treatments } \\
\hline & \multirow[t]{2}{*}{ Urea } & \multirow{2}{*}{$\begin{array}{c}\text { Poultry } \\
\text { Droppings }\end{array}$} & \multirow{2}{*}{$\begin{array}{l}\text { Piggery } \\
\text { Dung }\end{array}$} & \multirow{2}{*}{$\begin{array}{c}\text { NPK } \\
\text { 20:10:10 }\end{array}$} & \multirow[t]{2}{*}{ Control } \\
\hline & & & & & \\
\hline $\mathrm{pH}\left(\mathrm{H}_{2} \mathrm{O}\right)$ & 5.70 & 5.10 & 5.50 & 5.10 & 5.40 \\
\hline Organic Carbon (\%) & 1.05 & 1.66 & 1.56 & 1.60 & 1.56 \\
\hline Organic matter $(\%)$ & 1.81 & 2.86 & 2.69 & 2.76 & 2.69 \\
\hline Total Nitrogen $(\%)$ & 0.84 & 0.56 & 0.28 & 0.56 & 0.28 \\
\hline C/N Ratio & 1.3 & 3.0 & 5.6 & 2.9 & 5.6 \\
\hline $\begin{array}{l}\text { Exchangeable acidity } \\
\left(\mathrm{cmolkg}^{-1}\right)\end{array}$ & 1.42 & 1.54 & 1.54 & 1.22 & 1.54 \\
\hline \multicolumn{6}{|l|}{$\begin{array}{l}\text { Exchangeable cations } \\
\left(\mathrm{cmolkg}^{-1}\right)\end{array}$} \\
\hline $\mathrm{Ca}^{2+}$ & 12.7 & 12.4 & 8.8 & 13.1 & 12.2 \\
\hline $\mathrm{Mg}^{2+}$ & 1.10 & 1.60 & 1.00 & 0.40 & 0.70 \\
\hline Available P $\left(\mathrm{mgkg}^{-1}\right)$ & 29.81 & 29.81 & 35.08 & 43.85 & 29.81 \\
\hline$\%$ sand & 83.2 & 87.2 & 85.2 & 83.2 & 87.2 \\
\hline$\%$ Silt & 8.0 & 4.0 & 4.0 & 4.0 & 4.0 \\
\hline$\%$ Clay & 8.8 & 8.8 & 1.08 & 12.8 & 8.8 \\
\hline Texture & Sandy loam & Sandy loam & Sandy loam & Sandy loam & Sandy loam \\
\hline
\end{tabular}

\subsection{Effect of Nitrogenous Amendments on Growth and Yield of Castor Bean}

Germination for all treatments was observed to be between 6 to 10 days after planting (Fig. 1). The soil amendments negatively affected germination, with only the control having $100 \%$ germination, and all the others $70 \%$. This may have been due to the acidic nature of the soil amendments used.

There were significant differences among treatments with respect to plant heights, at both the 6 and 8 weeks after planting (WAP). Plant height at 8WAP was in the order 52.6>39.7> $37.3>$ $24.5>17.4 \mathrm{~cm}$ for piggery dung, poultry droppings, NPK 20-10-10, control and urea 
respectively (Fig.2). Results showed that only urea amended soils depressed plant heights. There are similar findings on the effect of urea on plant parameters (Makinde et. al., 2011, Amin 2011, Hozhbryn 2013).

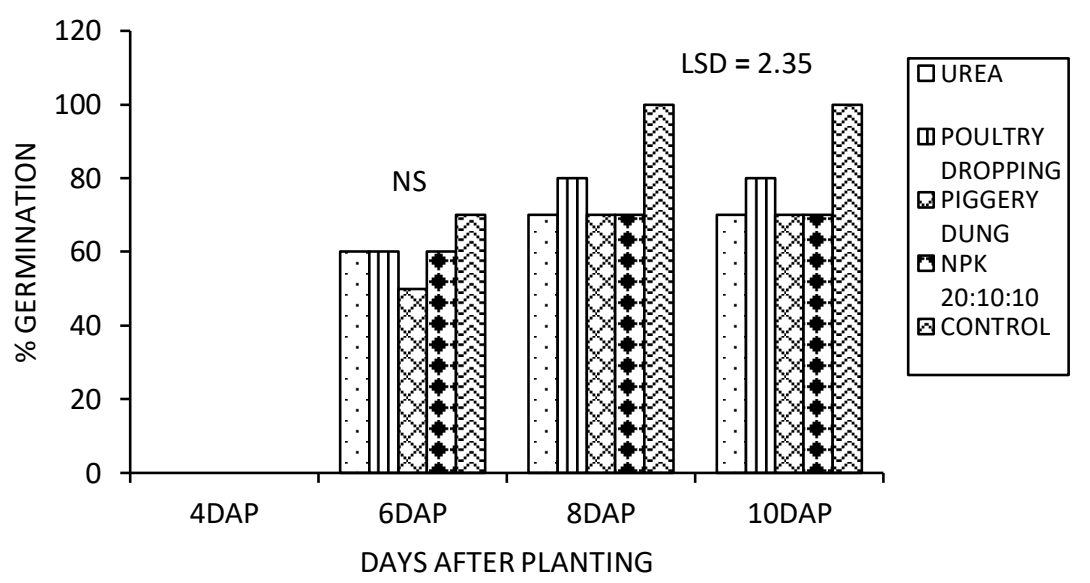

Fig. 1: Effect Of Various Nitrogen Sources On Percentage Germination

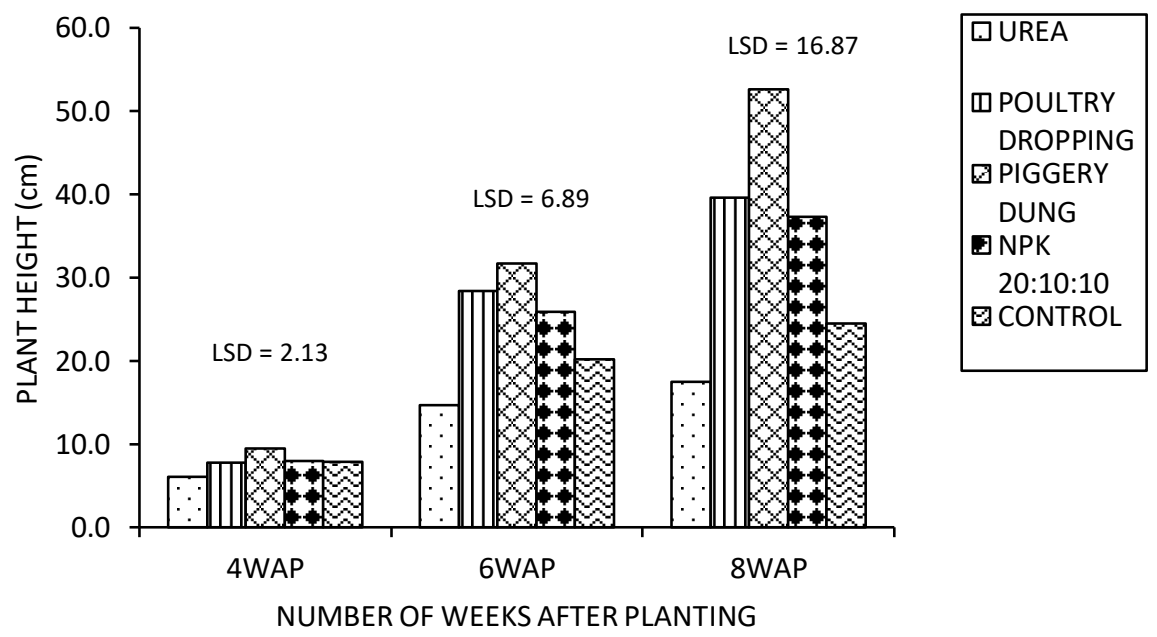

Fig. 2: Effect Of Various Nitrogen Sources On Plant Height

The trend was the same with number of leaves (Fig. 3) and leaf area (Fig. 4). Urea appears to harm seeds and seedlings and may be better used before seed or transplanting or after the plant growers larger. This is in addition, to the fact that it tends to lower soil $\mathrm{pH}$ and therefore affect 
other nutrient availability. Piggery dung amended soils had number of leaves (15.7) and leaf area $\left(296.7 \mathrm{~cm}^{2}\right)$ values significantly higher than the control, with 8.0 and $162.7 \mathrm{~cm}^{2}$ for number of leaves and leaf area respectively.

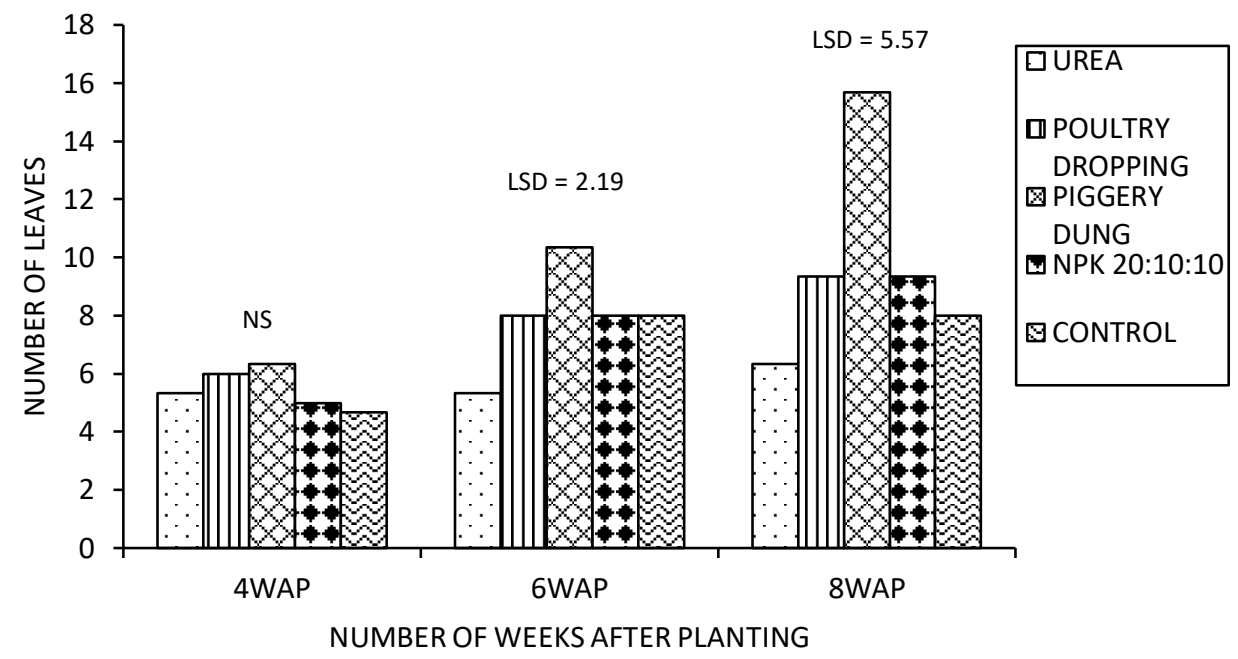

Fig. 3: Effect Of Various Nitrogen Sourceson Number Of Leaves

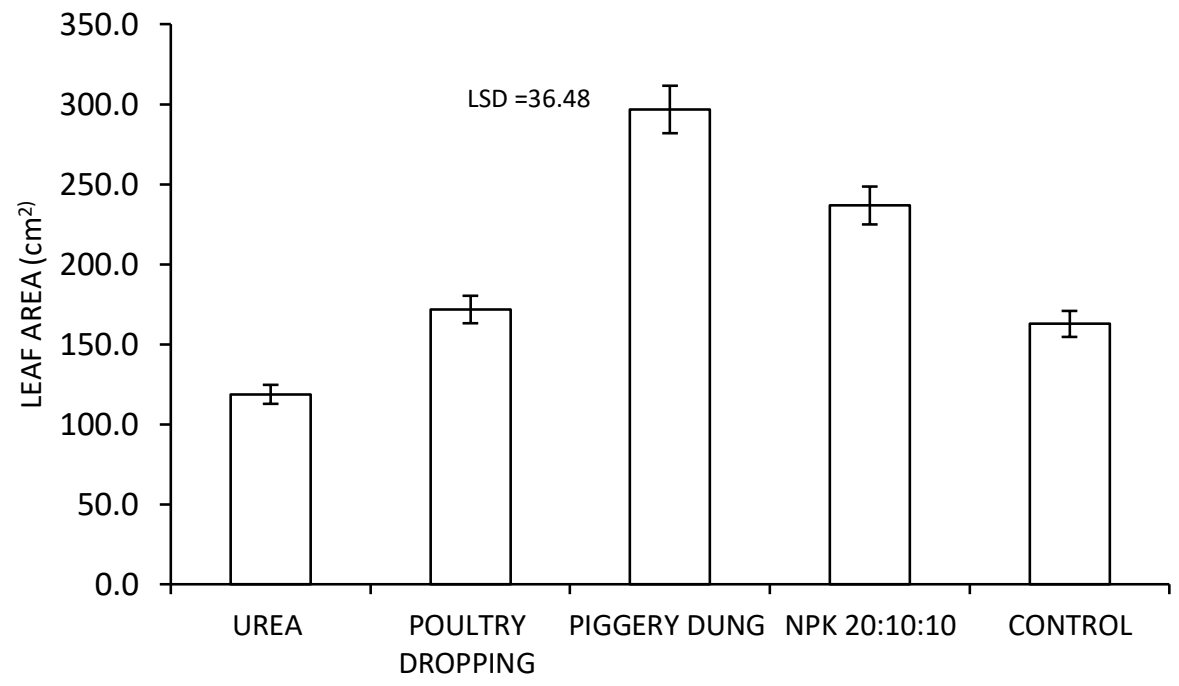

Fig. 4: Effect Of Various Nitrogen Sources On Leaf Area 
Piggery dung and NPK 20-10-10 significantly increased both number of capsules and weight of capsules per plant, when compared with the control (Figs. 5 and 6). The number of capsules was in the order: $96.3>88.3>40.0>19.0>18.0$ capsules per plant for NPK 20-10-10, piggery dung, control, poultry droppings and urea respectively. For the capsule weights, it was in the order $141.0>78.9>28.4>12.8>11.5$ gplant $^{-1}$ for piggery dung, NPK 20-10-10, control, poultry droppings and urea respectively. This may be as a result of the higher available phosphorus contents in these when compared with the other treatments. Phosphorus is an essential nutrient element for grain filling in plants. It is also reported in previous works that piggery dung contains more available phosphorus than poultry droppings (Buckley and Markortff, 2004).

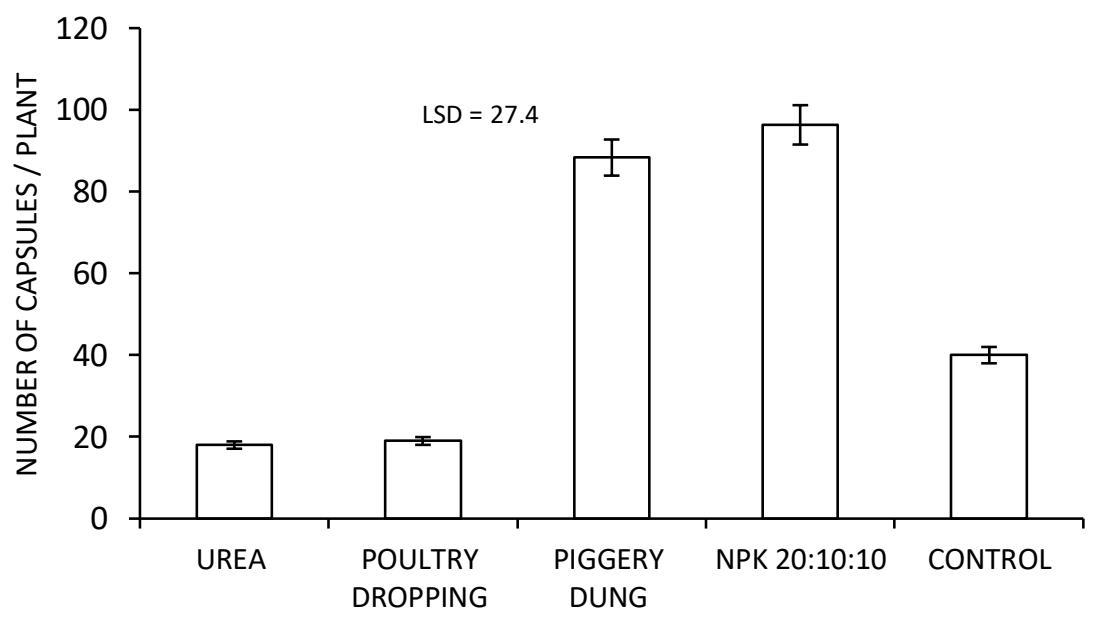

Fig. 5: Effect Of Various Nitrogen Sources On Number Of Capsules Per Plant 


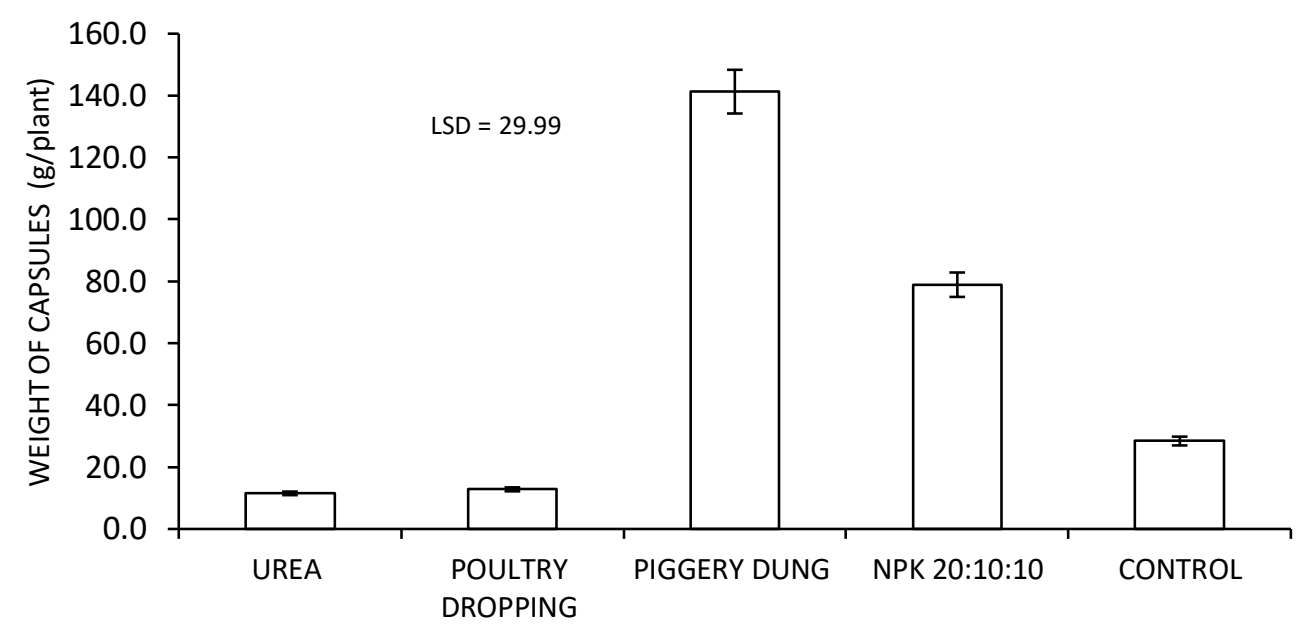

Fig. 6: EFFECT OF VARIOUS NITROGEN SOURCES ON WEIGHT OF CAPSULES (G/Plant)

\section{CONCLUSION}

The findings of this work show that amending the soil with materials that will supply copious available nitrogen and phosphorus, like the piggery dung and NPK 20-10-10, will increase the yield of castor bean plant by over $100 \%$. However, given that the piggery dung, in addition to higher yields, is more soil environmental friendly when compared with NPK 20-10-10 it is recommended for better castor bean production.

\section{REFERENCES}

Amin, M. E. H. (2011). Effect of different nitrogen sources on growth, yield and quality of fodder maize (Zea mays L.). Jour. Saudi soc.agric sci. 10:17-23

Buckley, K. and Makortoff, M. (2004). Phosphorus in livestock manure. In: Advanced Silage Corn Management.

Bittman, S and Kowalenko, C.G. ed. Pacific Field Corn Association, Agassiz BC. www.farmwest.com/node/953

Eno, J.U, Trenchard, O.I, Joseph, A.O, Anthony, O.A. and Ivara, E. E. (2009). Manual of Soil, Plant and Water Analyses. Sibon Books Limited. Lagos. ISBN 978-8012-71-X. 
International Journal of Agriculture and Environmental Research

ISSN: 2455-6939

Volume: 06, Issue: 03 "May-June 2020"

Hussein, M. M., El-Saady, A. M. and Abou-Baker, N. H. (2015). Castor bean plants response to phosphorus sources under irrigation by diluted seawater. International Journal Chemical Technology Research, 8(9), 261-271.

Hozhbryan, M. (2013). Effects of different levels of urea on the growth and yield of tomato. Jour. of Novel Appl. Sci. 2 (3) 1031-1035.

Lal, R. (1986). Soil surface management in the tropics of intensive land use and high sustainable production. Advances in Soil Sci. 5:1-104.

Mabuza, M.P. and Mabuza, D. (2019). Effects Of Nitrogen And Phosphorus Fertiliser Rates On The Growth Rate and Yield of Castor Bean (Ricinus communis [L.]) In The Wet Middleveld Of Eswatini. Int'l Jour. of Agric., Environ. and Bio. 4(4). 54-64.

Makinde, O., Usilo, M. I., Makinde, E. A. and Ayeni, L. S. (2011). Comparative Effect of Mineral Fertilizers and Organic Manures on Growth, Nutrient Content and Yield of Chorcorus olitorus and Celosia argentina. Research Journal of Botany, 6: 150-156.

Okonkwo, G.I. and Mbajiorgu, C.C. (2010). Rainfall intensity-duration-frequency analysis for Southeastern Nigeria. Agric Eng Int: CIGR Jour., 12(1):22-30.

Orji, O.A. and Eke, P. (2018). Effect of Mulch Materials on Soil Physico-Chemical Properties and The Performance of Castor Bean Plant (Ricinus communis) In Rivers State, Nigeria. Indian Jour. Agric. Res., 52(6), 649-654.

Page, A. L., Miller, R. H., and Keeny, D. R. (1982). Methods of Soil Analysis Part 2: Chemical and Microbiological Properties. 2nd ed. Agronomy; 9 Soil Sci. Soc. Am., Madison WI pp. 1143.

Reddy, K. R. and Matcha, S. K. (2010). Quantifying nitrogen effects on castor bean (Ricinus communis L.) development, growth, and photosynthesis. Industrial Crops and products, 31(1), 185-191.

Weiss, E. A. (2000). Castor Oilseed Crops. UK Blackwell Science, 13-52. 